\title{
The path to microRNA therapeutics in psychiatric and neurodegenerative disorders
}

\author{
Anthony W. S. Chan ${ }^{1,2}$ and Jannet Kocerha ${ }^{1,2 *}$ \\ 1 Yerkes National Primate Research Center, Atlanta, GA, USA \\ 2 Department of Human Genetics, Emory University School of Medicine, Atlanta, GA, USA
}

Edited by:

Michael Rossbach, Genome Institute of Singapore, Singapore

Reviewed by:

Gerard J. Nuovo, Ohio State University Medical Center, USA Angela Pearson, INRS-Institut

Armand-Frappier, Canada

*Correspondence:

Jannet Kocerha, Yerkes National

Primate Center, Emory University, 954 Gatewood Road North East,

Atlanta, GA 30329, USA.

e-mail: jannet.kocerha@emory.edu
The microRNA (miRNA) class of non-coding RNAs exhibit a diverse range of regulatory roles in neuronal functions that are conserved from lower vertebrates to primates. Disruption of miRNA expression has compellingly been linked to pathogenesis in neuropsychiatric and neurodegenerative disorders, such as schizophrenia, Alzheimer's disease, and autism. The list of transcript targets governed by a single miRNA provide a molecular paradigm applicable for therapeutic intervention. Indeed, reports have shown that specific manipulation of a miRNA in cell or animal models can significantly alter phenotypes linked with neurological disease. Here, we review how a diverse range of biological systems, including Drosophila, rodents, and primates such as monkeys and humans, can be integrated into the translation of miRNAs as novel clinical targets.

Keywords: microRNAs, psychiatric, neurodegeneration, non-coding RNA, therapeutics, schizophrenia, monkeys, primates

\section{INTRODUCTION}

The multi-functional role of RNA as a molecular regulator spans a broad range of classifications as protein-coding and non-protein coding RNA transcripts. Notably, the microRNA (miRNA) class of non-coding RNAs have been implicated in a vast majority of the established signaling cascades (Bartel, 2009). Brain-localized miRNAs are of particular interest for neurological diseases which have a complex etiology and no currently effective therapeutic options. The transcriptomic targets of an miRNA can encompass numerous cellular pathways, consistent with the extensive molecular disruption linked to neurological disease onset. In this review, we discuss how various model systems can be integrated into the translation of miRNAs as novel clinical targets in the treatment of neuropsychiatric and neurodegenerative disorders.

\section{CONSERVED ROLE OF NEURONAL mIRNAS}

The conserved role of miRNAs in neuronal functions underscores their relevance in the molecular dynamics between normal and pathogenic mechanisms. Indeed, Drosophila, rodents, monkeys, and humans have all shown significant sensitivity to microRNA modulation (Jin et al., 2004; Ashraf et al., 2006; Elmen et al., 2008; Hollander et al., 2010). Notably, some core components of the miRNA processing machinery, guided by the RNA-induced silencing complex (RISC), are shared between lower vertebrates and primates, such as the Argonaute-interacting proteins, GW182 (Chekulaeva and Filipowicz, 2009; Chekulaeva et al., 2011) and the 5 ' pocket motif of the Dicer-homologs (Park et al., 2011). Furthermore, regulation of long-term memory processes and associated synaptic proteins are controlled by the miRNA RISC pathway in a diverse group of species (Ashraf et al., 2006; Rajasethupathy et al., 2009; Gao et al., 2010; Konopka et al., 2010). Collectively, the previous reports indicate that epigenetic modulation by miRNAs are a principal component to central nervous system development and homeostasis.
Several of the more extensively reported brain-enriched miRNAs, such as miR-9, miR-34, miR-124, miR-128, miR132, miR-219, have predominantly identical mature sequences across species, including humans, monkeys, mice, and Drosophila (Kapsimali et al., 2007; Hu et al., 2011; Juhila et al., 2011). The conservation of those miRNAs spans from the $5^{\prime}$ seed region to the $3^{\prime}$ end of the transcript. Moreover, the precursor sequence for some of the brain-enriched miRNAs, including miR-9 and miR-124, are also identical between humans and mice, further supporting a highly conserved function for those transcripts.

\section{MIRNA REGULATION IN NEUROPSYCHIATRIC AND NEURODEGENERATIVE DISORDERS}

In the past few years, an extensive list of published reports have emerged to support a significant role for miRNAs in the pathogenesis of psychiatric and neurodegenerative disease (Bilen et al., 2006; Lukiw, 2007; Hebert et al., 2008, 2009; Li et al., 2008, 2011; Wang et al., 2009, 2010, 2011; Beveridge et al., 2010; Nelson and Wang, 2010; Nunez-Iglesias et al., 2010; Shioya et al., 2010; Chandrasekar and Dreyer, 2011; Kocerha et al., 2011; Lee et al., 2011; Santarelli et al., 2011; Smith et al., 2011; Liu et al., 2012b). The pathogenic mechanisms underlying the development of psychiatric deficits and neurodegeneration are not always distinct, suggesting they may be ideally suited for therapeutic targeting by pleiotropic miRNAs. Reports have shown that the precursor and mature miRNA transcripts as well as the miRNA processing machinery itself, such as Drosha and Dicer, are all subject to disruption with neurological disease progression (Sun et al., 2009; Beveridge et al., 2010; Babiarz et al., 2011; Fenelon et al., 2011; Schofield et al., 2011). Notably, the miRNA-linked pathology can be provoked through either genetic or non-genetic (sporadic) anomalies (Rademakers et al., 2008; Kocerha et al., 2011).

Schizophrenia, autism, Fragile X syndrome, depression, addiction, and anxiety are a few examples of psychiatric diagnoses where 
altered miRNA profiles have been identified, and a summary of the dysregulated miRNAs and the biological source they were profiled from are outlined in Table 1 (Jin et al., 2004; Abu-Elneel et al., 2008; Li et al., 2008; Pietrzykowski et al., 2008; Hunsberger et al., 2009; Yang et al., 2009; Zhou et al., 2009; Zhu et al., 2009; Beveridge et al., 2010; Hollander et al., 2010; Im et al., 2010; Sarachana et al., 2010; Saus et al., 2010; Xu et al., 2010a,b; Baudry et al., 2011a,b; Eipper-Mains et al., 2011; Ghahramani Seno et al., 2011; Haramati et al., 2011; Mouillet-Richard et al., 2011; O’Connor et al., 2011; Shaltiel et al., 2012). In schizophrenia, miRNA profiling has now been completed in several patient populations, primarily focused within the cortex (Perkins et al., 2007; Beveridge et al., 2010; Kim et al., 2010; Moreau et al., 2011; Santarelli et al., 2011). Although a majority of the miRNA profiling studies for neurological disease have been performed from brain, miRNA dysregulation has also been observed in other sources such as cerebral spinal fluid
(CSF), plasma, serum, and peripheral blood (Schipper et al., 2007; Cogswell et al., 2008; Gardiner et al., 2011; Ghidoni et al., 2011; Lai et al., 2011). Beveridge and Cairns (2011) recently reviewed the various studies to compare and contrast the collection of miRNA results in schizophrenia. Interestingly, a few of the miRNA families, including the miR-15 and miR-30 families, have consistently shown disruption in several of the population analyses (Beveridge and Cairns, 2011). We examined the bioinformatic mRNA targets of miR-15 and miR-30 with Targetscan and found several mRNAs which are strongly linked with schizophrenia, including neuregulin and synaptotagmin (Kim et al., 2007; Kao et al., 2010).

Psychiatric symptoms can also co-exist in patients with neurodegenerative pathology, such as Huntington's disease (HD), Frontotemporal dementia (FTD), Alzheimer's disease (AD), Parkinson's disease (PD), and amyotrophic lateral sclerosis (ALS),

Table 1 | miRNAs associated with neuropsychiatric disease.

\begin{tabular}{|c|c|c|c|}
\hline Disease & Associated miRNAs & Biological profiling source & Reference \\
\hline \multirow[t]{4}{*}{ Schizophrenia } & $\begin{array}{l}\text { 106b, 107, 128a, 134, 150, 15a, 15b, 16, 17, 181a, 181b, } \\
\text { 195, 199a*, 19a, 20a, 20b, 212, 219, 24, 25, 26b, 27a, } \\
\text { 29a, 29b, 29c, 30a-5p, 30b, 30d, 30e, 328, 346, 382, } \\
\text { 487a, 9-3p, 92, let-7d, let-7e, 652, } 7\end{array}$ & $\begin{array}{l}\text { Human cortex (temporal and } \\
\text { prefrontal) }\end{array}$ & $\begin{array}{l}\text { Beveridge et al. (2008, 2010), Zhu et al. } \\
\text { (2009), Perkins et al. (2007), Santarelli et al. } \\
\text { (2011) }\end{array}$ \\
\hline & 219 & $\begin{array}{l}\text { Cortex from mouse model of } \\
\text { schizophrenia }\end{array}$ & Kocerha et al. (2009) \\
\hline & $137,30 e$ & Human genomic DNA & Ripke et al. (2011), Xu et al. (2010a) \\
\hline & $30 e, 34 a, 449 a, 564,432,548 d, 572,652$ & Human blood & Xu et al. (2010a), Lai et al. (2011) \\
\hline $\begin{array}{l}\text { Schizophrenia } \\
\text { or bipolar } \\
\text { disorder }\end{array}$ & $\begin{array}{l}106 b, 132^{*}, 132,133 b, 138,140-3 p, 145^{*}, 145,148 b, \\
151,154^{*}, 15 a, 181 a, 186,190,192,193 a, 193 b, 210, \\
212,22^{*}, 22,27 b, 29 a, 301,32,324-3 p, 33,330,338, \\
339,34 a, 425,454^{*}, 504,520 c-3 p, 544,545,573,639 \\
7,767-5 p, 874,889,99 a\end{array}$ & Human cortex & Moreau et al. (2011), Kim et al. (2010) \\
\hline \multirow[t]{2}{*}{ Autism } & $\begin{array}{l}\text { 106a, 106b, 128, 129, 132, 140, 146b, 148b, 15a, 15b, } \\
181 d, 193 b, 21,212,23 a, 27 a, 320 a, 381,431,432, \\
484,539,550,598,652,7,93,95\end{array}$ & Human cerebellum & Abu-Elneel et al. (2008) \\
\hline & $\begin{array}{l}\text { 103, 106b, 107, 10a, 125b, 132, 133b, 136, 139, 148b, } \\
153-1,16-2,182-A S, 185,186,189,190,191,194,195, \\
196 a, 199 a-5 p, 199 b, 199 b-5 p, 205,211,219,23 a, 23 b, \\
25,29 b, 30 c, 326,338-3 p, 346,367,376 a-A S, 451,455, \\
455-3 p, 486-3 p, 486-5 p, 495,518 a, 519 c, 520 b, 524 \\
577,650,93\end{array}$ & Lymphoblastoid cell lines & $\begin{array}{l}\text { Sarachana et al. (2010), Ghahramani Seno } \\
\text { et al. (2011) }\end{array}$ \\
\hline \multirow[t]{3}{*}{ Depression } & 16 & $\begin{array}{l}\text { Mouse serotonergic raphe } \\
\text { nuclei }\end{array}$ & Baudry et al. (2011a,b) \\
\hline & $182,30 e$ & Human genomic DNA (blood) & Saus et al. (2010), Xu et al. (2010b) \\
\hline & $\begin{array}{l}\text { 101, 10a, 130a, 137, 142-3p, 142-5p, 146a, 148b, 155, } \\
\text { 190, 20a, 20b, 27a, 301a, 324-5p, 335, 376a* , 489, 494, } \\
497,660\end{array}$ & Human prefrontal cortex & Smalheiser et al. (2012) \\
\hline \multirow[t]{3}{*}{ Addiction } & $212,132,124$, let-7d, 181a & $\begin{array}{l}\text { Brain tissue from rat cocaine } \\
\text { addiction model }\end{array}$ & $\begin{array}{l}\text { Hollander et al. (2010), Chandrasekar and } \\
\text { Dreyer (2011) }\end{array}$ \\
\hline & $\begin{array}{l}\text { 103, 125b-5p, 127, 138, 181a, 24, 26a, 29a, 29b, 30a, } \\
\text { 30c, 30d, 30e, 7a, 7b, 7c, 7c, 9, let-7a, let-7f, let-7g }\end{array}$ & $\begin{array}{l}\text { Brain tissue from mouse } \\
\text { cocaine addiction model }\end{array}$ & Eipper-Mains et al. (2011) \\
\hline & 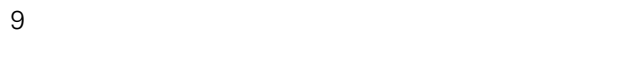 & $\begin{array}{l}\text { Striatal neuronal cultures for } \\
\text { model of alcohol exposure }\end{array}$ & Pietrzykowski et al. (2008) \\
\hline Anxiety & 132,34 & $\begin{array}{l}\text { Brain tissue from mouse model } \\
\text { of anxiety }\end{array}$ & Shaltiel et al. (2012), Haramati et al. (2011) \\
\hline
\end{tabular}


all of which have shown miRNA disruption and is summarized in Table 2 (Wang et al., 0000; Hebert et al., 2008; Packer et al., 2008; Hebert and De Strooper, 2009; Williams et al., 2009; Haramati et al., 2010; Jiao et al., 2010; Lau and de Strooper, 2010; Buckley and Johnson, 2011; Gaughwin et al., 2011; Kocerha et al., 2011; Lee et al., 2011; Martins et al., 2011; MinonesMoyano et al., 2011; Smith et al., 2011; Enciu et al., 2012; Mouradian, 2012). A pivotal role for miRNAs in neurodegenerative disease is further supported by numerous reports linking miRNAs with neurogenesis and neurodegenerative signaling cascades, and thus, overall neuronal density (Patel et al., 2008; Boissonneault et al., 2009; Gao, 2010; Magill et al., 2010; Schonrock et al., 2010; Shi et al., 2010; Cho et al., 2011; Shibata et al., 2011; Tao et al., 2011; Han et al., 2012; Persengiev et al., 2012).

Some miRNAs, such as miR-132, have been shown to be dysregulated in both psychiatric and neurodegenerative disease. miR-132 has been linked with schizophrenia (Perkins et al., 2007; Kim et al., 2010), addiction (Hollander et al., 2010), HD (Lee et al., 2011), AD (Cogswell et al., 2008), and progressive supranuclear palsy (PSP; Smith et al., 2011). Indeed, the wide range of neurological diseases in which miR-132 is disrupted is consistent with its principal role in neuronal plasticity and related functions (Magill et al., 2010; Remenyi et al., 2010; Mellios et al., 2011; Shaltiel et al., 2012).

\section{NON-PRIMATE MODELS AND mIRNA THERAPEUTIC DISCOVERY}

A selection of cell and animal models have been engaged in the preliminary search for miRNAs with clinical relevance for neurological disease. Cell lines, primary cell cultures, differentiated neurons, and induced pluripotent stem (iPS) cells are a few of the platforms that have effectively been utilized for in vitro analyses (Cole et al., 2008; Agostini et al., 2011; Arias-Carrion and Salama, 2011; Kim et al., 2011; Saba et al., 2012). Indeed, cell-based systems have led to successful large-scale screening studies as well as in-depth molecular analysis of functional miRNAs (Vo et al., 2005; Cole et al., 2008; Connelly et al., 2012). For example, the discovery that neuronally enriched miR-132 is regulated by cAMP-response element binding protein (CREB) was initiated through a genomewide screen in rat PC12 neuronal cells (Vo et al., 2005). Not all miRNAs will have a functional biological role, however, cell-based screens can facilitate the identification of promising candidates.

In parallel with the in vitro findings, studies in non-primate animal models have significantly advanced our understanding of miRNA biology in psychiatric and neurodegenerative disorders (Kocerha et al., 2009; Hollander et al., 2010; Lee et al., 2011; Li et al., 2011). Animal studies are a critical step in the progression toward testing of miRNA-based therapeutics in clinical trials. Our group examined the regulation of miRNAs in mice with pharmacological induction of a schizophreniaassociated behavioral phenotype (Kocerha et al., 2009). Likewise, a neurotoxin induced mouse model (1-methyl-4-phenyl-1,2,3,6tetrahydropyridine; MPTP) for Parkinson's disease (PD) was used to uncover a role for miR-7 in PD pathology (Junn et al., 2009). In addition to pharmacologically treated animal models, transgenic, knock-out and knock-in mice have also been valuable in vivo resources (Lee et al., 2011; Tao et al., 2011). Indeed, transgenic expression of the AD-causative amyloid precursor protein (APP) gene in mice provoked significant disruption in neuronal miRNA expression (Schonrock et al., 2010).

In addition to mice, rats as well as zebrafish and other vertebrate species have been integral in the study of neuronal miRNA pathways prior to testing in primate models (Yang et al., 2011; Tal et al., 2012). Indeed, recent reports identified miRNAs in zebrafish directly linked to neurobehavioral responses and neuronal differentiation (Tal et al., 2012). The exploration of miRNAs which regulate central nervous system functions, however, is not limited to vertebrate species. Drosophila, an invertebrate model, have been widely used for many years to examine or further define molecular mechanisms. Moreover, studies in Drosophila recently revealed that the conserved miRNA miR-34 mediates aging and neurodegenerative processes (Liu et al., 2012a), further substantiating that all biological models are applicable in the investigation of non-coding RNAs. Additionally, as each miRNA may regulate a number of transcripts and therefore off-target effects may result when altered, animal and cell models may help to filter out those candidates.

\section{PRIMATE MODELS AND mIRNA PRE-CLINICAL EVALUATION}

Arguably, a principal goal in the field of non-coding RNAs, including miRNAs, is to uncover transcripts which can ultimately lead to advancements in human health. Correspondingly, there are numerous studies which have profiled miRNA expression from humans with and without a disease diagnosis. Although some of those reports have focused on peripheral tissues, a subset of those analyses have specifically examined miRNA transcripts in distinct brain regions (Hebert et al., 2008; Kocerha et al., 2011; Santarelli et al., 2011). Genome-wide association (GWAS) studies and microarray profiling have both been used to identify miRNAs which are potential disease risk factors for neurodegenerative and psychiatric disorders (Rademakers et al., 2008; Hollander et al., 2010; Kocerha et al., 2011; Richardson et al., 2011; Ripke et al., 2011). Furthermore, there can be disruption of a cluster or multiple members within an miRNA family, such as with miR-29. In brain tissue from a cohort of Alzheimer's patients, miR-29a and miR-29b expression were both significantly repressed in patients with increased levels of beta-secretase/BACE1 (Hebert et al., 2008). $B A C E 1$ is a direct mRNA target for the miR-29 family and has consistently been linked to AD pathology. Therefore, correlation of expression for a miRNA and its targets in the transcriptome, as well as identification of disruption in miRNA families, can all contribute to effective discovery of new treatment alternatives for diagnosed patients.

The brain structure and related functions of humans and monkeys are strikingly similar (King and Wilson, 1975; McConkey and Varki, 2000; Paabo, 2001; Perkins et al., 2010; de Araujo et al., 2012), suggesting that monkeys are a relevant primate model for pre-clinical investigation of miRNAs in neurological dysfunction. Notably, certain key cell types in the brain linked to disease pathology, such as mirror neuron disruption in autism (Perkins et al., 2010), are primarily specific to primate physiology. Moreover, there is extensive conservation in miRNAs between primates, including those which are localized in the central nervous system 
Table 2 | miRNAs associated with neurodegenerative disease.

\begin{tabular}{|c|c|c|c|}
\hline Disease & Associated miRNAs & Biological profiling source & Reference \\
\hline \multirow[t]{3}{*}{$\begin{array}{l}\text { Huntington's } \\
\text { disease (HD) }\end{array}$} & $\begin{array}{l}\text { 100, 125b, 127-3p, 135a, 135b, 138, 145, 146, 146a, } \\
\text { 148a, 150, 181c, 190, 199a-3p, 199a-5p, 200a, 205, 214, } \\
218,221,222,335,338-3 p, 9 *, 9\end{array}$ & Huntington cell lines & Ghose et al. (2011), Sinha et al. (2010) \\
\hline & $34 b$ & Human plasma & Gaughwin et al. (2011) \\
\hline & $\begin{array}{l}1-1,124 a, 128,132,133 a, 135 b, 138,203,204,21,218, \\
22,222,29 a, 29 b-1,29 c, 330,344,346,674 *, 9-1,9-3\end{array}$ & $\begin{array}{l}\text { Brain tissue from trans- } \\
\text { genic HD mice }\end{array}$ & Lee et al. (2011), Johnson et al. (2008) \\
\hline \multirow[t]{3}{*}{$\begin{array}{l}\text { Frontotemporal } \\
\text { dementia (FTLD) }\end{array}$} & $922,516 a-3 p, 571,548 b-5 p, 548 c-5 p$ & $\begin{array}{l}\text { Human cortex and cerebel- } \\
\text { lum }\end{array}$ & Kocerha et al. (2011) \\
\hline & $29 b, 107$ & Cell cultures & Wang et al. (2010), Jiao et al. (2010) \\
\hline & 659 & Human genomic DNA & Rademakers et al. (2008) \\
\hline \multirow{3}{*}{$\begin{array}{l}\text { Parkinson's dis- } \\
\text { ease (PD) }\end{array}$} & $\begin{array}{l}50,83,58,77,238,1,48,65,64,80,84, \text { let- } 7,236,51 \\
241,230,\end{array}$ & C. elegans & Asikainen et al. (2010) \\
\hline & $10 a, 10 b, 212,132,495$ & Mouse model for PD & Gillardon et al. (2008) \\
\hline & let-7, 184* & Drosophila & Gehrke et al. (2010) \\
\hline $\begin{array}{l}\text { Amylotrophic } \\
\text { lateral sclerosis } \\
\text { (ALS) }\end{array}$ & 206 & Mouse model for ALS & Williams et al. (2009) \\
\hline \multirow{3}{*}{$\begin{array}{l}\text { Alzheimer's dis- } \\
\text { ease (AD) }\end{array}$} & $137,181 c, 9,29 a, 29 b, 34 a, 181 b$ & Human blood & Geekiyanage et al. (2011), Schipper et al. (2007) \\
\hline & $137,181 c, 9,29 a, 29 b$ & Human serum & Geekiyanage et al. (2011) \\
\hline & $105,10 a, 10 b, 125 a, 126 *, 126,127,135 a, 138,141$ & Human CSF & Cogswell et al. (2008) \\
\hline
\end{tabular}
142-5p, 143, 146b, 151, 154, 15b, 181a, 181c, 186, 191, $194,195,197,199 a^{*}, 204,205,214,216,221,302 b$, 30a-3p, 30a-5p, 30b, 30c, 30d, 32, 338, 345, 362, 371, $374,375,380-3 p, 422 b, 429,448,449,451,455,494$, 497, 501, 517a, 517b, 518b, 518f, 520a*, 526a, 7f, 99a $125 b, 106 b, 107,124,132,145,146 b, 148 a, 17-5 p, 200 c$, $20 a, 210,212,26 a, 27 a, 27 b, 30 c, 30 e-5 p, 34 a, 381$, $422 a, 423,425,9,92$, let-7b, 100

106a, 106b, 125b, 137, 146a, 147, 148b, 153, 17, 17-5p, 181c, 187, 20a, 20b, 21, 212, 26a, 27a, 298, 301, 30b, 30c, 30e-5p, 323-3p, 328, 34a, 361, 365, 376b, 381, 409, 422a, 423, 433, 520c, 644, 655, 664, 700, 7g, 7i, 9,92

$34 a, 103,107,146 a, 106 b, 16,34 c, 20 a, 17-5 p$

Human brain

Cogswell et al. (2008), Hebert et al. (2009), Smith et al. (2011), Wang et al. (2008)

Cell cultures

Long and Lahiri. (2011), Kim et al. (2011), Boissonneault et al. (2009), Patel et al. (2008), Schonrock et al. (2010), Delay et al. (2011), Hebert et al. (2009), Smith et al. (2011)

$A D$ mice models

Yao et al. (2010), Li et al. (2011), Wang et al. (2009, 2010), Liu et al. (2012b), Zovoilis et al.

214, 23a, 23b, 486-3p, 30e* 143, 128, 27a, 27b, $324-5 p, 422 a$

Bioinformatic single (2011), Hebert et al. (2009)

nucleotide polymorphism

(SNP) analysis 
(Brameier, 2010; Hu et al., 2011). One recent study reported that of the 413 miRNAs expressed in human brain, 366 of those transcripts are also detectable in rhesus macaque brain ( $\mathrm{Hu}$ et al., 2011). Correspondingly, a number of those miRNAs are also detectable in mouse cortex and hippocampus by microarray and sequencing efforts, such as miR-9, miR-124, miR-128, and miR132 (Juhila et al., 2011), suggesting that mouse models can be effective prior to testing in primates.

There have been considerable technological advancements in recent years with primate focused research, including with noncoding RNA biology. Groups have successfully delivered modifiedantisense oligonucleotides (ASO) into monkeys to inhibit the function of specific miRNAs with minimal off-target effects (Elmen et al., 2008; Petri et al., 2009; Lanford et al., 2010). To date, the ability to modulate miRNAs in primates is restricted to peripheral administration, however, delivery of potential therapeutics across the blood brain barrier could be a future attainable milestone. Progress has also been made in other capacities with primates, including with the generation of transgenic monkeys. Our group established the first transgenic rhesus macaques in 2001 (Chan et al., 2001), which subsequently led to the development of a cohort for HD transgenic monkeys (Yang et al., 2008), a resource directly applicable to assess miRNA functions in a primate model of neurodegenerative disease. Moreover, from the HD monkeys we derived iPS cells which display a progressive cellular phenotype (Chan et al., 2010), providing an in vitro platform to complement the in vivo analyses for therapeutic and biomarker discovery, including non-coding RNA targets.

In primates, the progression of neurodegeneration and psychiatric deficits is typically gradual, developing over years, rather than weeks or months. Correspondingly, longitudinal analyses of molecular and neurobehavorial changes are fundamental to the monitoring and subsequent discovery of new treatments (Insel, 2009; Thompson et al., 2011). Indeed, longitudinal studies are readily implementable in primate species such as monkeys and humans, including collection of peripheral blood samples for molecular analysis throughout disease progression and parallel correlation with brain morphology by magnetic resonance imaging (MRI; Thompson et al., 2011; Waber et al., 2012; Zhang et al., 2012). The correlation of miRNA expression with disease trajectories may help identify functional non-coding RNA transcripts involved in neuronal pathogenesis.

\section{APPROACHES FOR mIRNA MODULATION AND CLINICAL TRANSLATION}

As discussed above, a considerable number of in vitro and in vivo models are increasingly becoming available for miRNA functional studies. In conjunction, there have also been significant advances in the approaches to modulate or detect specific miRNAs. Viral and antisense-mediated targeting of non-coding transcripts are routinely applied to alter expression levels, however, technical improvements have allowed for increased effectiveness and efficacy. For example, locked nucleic-modified antisense oligonucleotides (LNA-ASO) significantly enhance the specificity and stability of miRNA silencing (Elmen et al., 2008; Stenvang et al., 2008; Kocerha et al., 2009; Hollander et al., 2010; Obad et al., 2011).
Notably, the LNA-ASO can be administered in vivo to animal models through different routes, such as intracerebroventricular (icv) delivery to penetrate multiple brain regions (Kocerha et al., 2009; He et al., 2010), or local stereotactic injections for site-specific miRNA silencing (Gao et al., 2010; Hollander et al., 2010). LNA-modified probes also intensify the detectability of non-coding RNAs for in situ localization (Havelda, 2010), which facilitates examination of less abundant transcripts. There are other chemical modifications available for ASO, such as $2^{\prime}-O$ methyl RNA, 2'-O-methyloxyethyl RNA, and phosphorothioate RNA (Ruberti et al., 2011), some of which have also been successfully utilized in the context of in vivo silencing (Cheng et al., 2009).

In addition to viral and antisense methods, nanoparticle delivery of neurogenic miRNAs provide a means for brain distribution of selected transcripts. Just recently, reports showed that rabies virus glycoprotein (RGV)-labeled nanomaterials resulted in specific delivery of miR-124 to neuronal cells (Hwang do et al., 2011). Nanotechnology has also been employed to silence miRNA function, such as with miR-122 conjugated to gold nanoparticles in myeloma cells (Crew et al., 2012), suggesting this technology is effective in the repression or stimulation of miRNA expression.

Importantly, silencing of miRNAs in animal embryos have also provided significant insight to their role in brain development. Recent reports have shown that injection of morpholinos to block miR-9 activity in the embryos of Xenopus tropicalis (Bonev et al., 2011) or zebrafish (Tal et al., 2012) substantially altered neuronal functions in the developing animals. Furthermore, overexpression or silencing of miR-9 via electroporation in mouse embryos revealed that Cajal Retzius neuronal cell differentiation is regulated through Forkhead box protein G1 (FOXG1; Shibata et al., 2008). Collectively, these reports indicate that miRNA activity can be modulated in vivo at various developmental stages to assess their implications in brain functions.

Overall, the technical developments in miRNA biology mentioned above facilitate the translation of select miRNA transcripts for future clinical intervention. Indeed, there are human trials currently being conducted to assess miRNA-modulation in disease pathogenesis, including the use of LNA-ASO (Seto, 2010; Montgomery and van Rooij, 2011). To date, the reported human trials have focused on miRNA regulation in peripheral organs, however, therapeutic targeting of the brain remains a future objective. Polymer (Cheng and Saltzman, 2012), lipid (Shi et al., 2012), and polylysine (Jin et al., 2012) based nanoparticle modulation of miRNAs has also been reported. Although a majority of the nanodelivery methods for miRNA studies have focused on nonneuronal cells, there is great potential for their application to the central nervous system.

\section{CONCLUSION}

The discovery and development of miRNA-based therapeutics, as well as the diverse range of molecular cascades they can regulate, offer a new approach for treating diseases with a heterogeneic or epigenetic origin. There are numerous psychiatric and neurodegenerative diseases with no effective treatments due to their 
complex etiology and therefore may be ideally positioned for clinical targeting of pleiotropic miRNAs.

\section{ACKNOWLEDGMENTS}

We thank Yerkes National Primate Research Center (YNPRC) veterinarian and animal care staff in providing outstanding

\section{REFERENCES}

Abu-Elneel, K., Liu, T., Gazzaniga, F. S., Nishimura, Y., Wall, D. P., Geschwind, D. H., Lao, K., and Kosik, K. S. (2008). Heterogeneous dysregulation of microRNAs across the autism spectrum. Neurogenetics 9, 153-161.

Agostini, M., Tucci, P., Steinert, J. R., Shalom-Feuerstein, R., Rouleau, M., Aberdam, D., Forsythe, I. D., Young, K. W., Ventura, A., Concepcion, C. P., Han, Y. C., Candi, E., Knight, R. A., Mak, T. W., and Melino, G. (2011). MicroRNA-34a regulates neurite outgrowth, spinal morphology, and function. Proc. Natl. Acad. Sci. U.S.A. 108, 21099-21104.

Arias-Carrion, O., and Salama, M. (2011). Reprogramming neurons by microRNAs into iPSCs to treat Parkinson's disease. Med. Hypotheses 77, 312-313.

Ashraf, S. I., McLoon, A. L., Sclarsic, S. M., and Kunes, S. (2006). Synaptic protein synthesis associated with memory is regulated by the RISC pathway in Drosophila. Cell 124, 191-205.

Asikainen, S., Rudgalvyte, M., Heikkinen, L., Louhiranta, K., Lakso, M., Wong, G., and Nass, R. (2010). Global microRNA expression profiling of Caenorhabditis elegans Parkinson's disease models. J. Mol. Neurosci. 41, 210-218.

Babiarz, J. E., Hsu, R., Melton, C., Thomas, M., Ullian, E. M., and Blelloch, R. (2011). A role for noncanonical microRNAs in the mammalian brain revealed by phenotypic differences in Dgcr8 versus Dicer1 knockouts and small RNA sequencing. RNA 17, 1489-1501.

Bartel, D. P. (2009). MicroRNAs: target recognition and regulatory functions. Cell 136, 215-233.

Baudry, A., Mouillet-Richard, S., Schneider, B., Launay, J. M., and Kellermann, O. (2011a). miR-16 a key for adaptive responses of neurons to fluoxetine. Med. Sci. (Paris) 27, 128-131.

Baudry, A., Mouillet-Richard, S., Schneider, B., Launay, J. M., and Kellermann, O. (2011b). miR-16 targets the serotonin transporter: a new facet for adaptive responses to antidepressants. Science 329, 1537-1541.
Beveridge, N. J., and Cairns, M. J. (2011). MicroRNA dysregulation in schizophrenia. Neurobiol Dis.

Beveridge, N. J., Gardiner, E., Carroll, A. P., Tooney, P. A., and Cairns, M. J. (2010). Schizophrenia is associated with an increase in cortical microRNA biogenesis. Mol. Psychiatry 15, 1176-1189.

Beveridge, N. J., Tooney, P. A., Carroll, A. P., Gardiner, E., Bowden, N., Scott, R. J., Tran, N., Dedova, I.., and Cairns, M. J. (2008). Dysregulation of miRNA $181 \mathrm{~b}$ in the temporal cortex in schizophrenia. Hum. Mol. Genet. 17, 1156-1168.

Bilen, J., Liu, N., Burnett, B. G., Pittman, R. N., and Bonini, N. M. (2006). MicroRNA pathways modulate polyglutamine-induced neurodegeneration. Mol. Cell 24, 157-163.

Boissonneault, V., Plante, I., Rivest, S., and Provost, P. (2009). MicroRNA298 and microRNA-328 regulate expression of mouse beta-amyloid precursor protein-converting enzyme 1. J. Biol. Chem. 284, 1971-1981.

Bonev, B., Pisco, A., and Papalopulu, N. (2011). MicroRNA-9 reveals regional diversity of neural progenitors along the anterior-posterior axis. Dev. Cell 20, 19-32.

Brameier, M. (2010). Genome-wide comparative analysis of microRNAs in three non-human primates. BMC Res. Notes 3, 64. doi:10.1186/1756-0500-3-64

Buckley, N. J., and Johnson, R. (2011). New insights into non-coding RNA networks in Huntington's disease. Exp. Neurol. 231, 191-194.

Chan, A. W., Cheng, P. H., Neumann, A., and Yang, J. J. (2010). Reprogramming Huntington monkey skin cells into pluripotent stem cells. Cell. Reprogram. 12, 509-517.

Chan, A. W., Chong, K. Y., Martinovich, C., Simerly, C., and Schatten, G. (2001). Transgenic monkeys produced by retroviral gene transfer into mature oocytes. Science 291, 309-312.

Chandrasekar, V., and Dreyer, J. L. (2011). Regulation of MiR-124, Let-7d, and MiR-181a in the accumbens affects the expression, extinction, and reinstatement of cocaine-induced conditioned place

services. YNPRC is supported by the National Center for Research Resources P51RR165 and is currently supported by the Office of Research and Infrastructure Program (ORIP)/OD P51OD11132. This study is supported by grant awarded by the ORIP/NIH (RR018827) and the American Recovery and Reinvestment Act (ARRA) Fund to Anthony W. S. Chan.

preference. Neuropsychopharmacology 36, 1149-1164.

Chekulaeva, M., and Filipowicz, W. (2009). Mechanisms of miRNAmediated post-transcriptional regulation in animal cells. Curr. Opin. Cell Biol. 21, 452-460.

Chekulaeva, M., Mathys, H., Zipprich, J. T., Attig, J., Colic, M., Parker, R., and Filipowicz, W. (2011). miRNA repression involves GW182-mediated recruitment of CCR4-NOT through conserved Wcontaining motifs. Nat. Struct. Mol. Biol. 18, 1218-1226.

Cheng, C. J., and Saltzman, W. M. (2012). Polymer nanoparticlemediated delivery of microRNA inhibition and alternative splicing. Mol. Pharm.

Cheng, L. C., Pastrana, E., Tavazoie, M., and Doetsch, F. (2009). miR-124 regulates adult neurogenesis in the subventricular zone stem cell niche. Nat. Neurosci. 12 , 399-408.

Cho, J. A., Park, H., Lim, E. H., and Lee, K. W. (2011). MicroRNA expression profiling in neurogenesis of adipose tissue-derived stem cells. J. Genet. 90, 81-93.

Cogswell, J. P., Ward, J., Taylor, I. A., Waters, M., Shi, Y., Cannon, B., Kelnar, K., Kemppainen, J., Brown, D., Chen, C., Prinjha, R. K., Richardson, J. C., Saunders, A. M., Roses, A. D., and Richards, C. A. (2008). Identification of miRNA changes in Alzheimer's disease brain and CSF yields putative biomarkers and insights into disease pathways. J. Alzheimers Dis. 14, 27-41.

Cole, K. A., Attiyeh, E. F., Mosse, Y. P., Laquaglia, M. J., Diskin, S. J., Brodeur, G. M., and Maris, J. M. (2008). A functional screen identifies miR-34a as a candidate neuroblastoma tumor suppressor gene. Mol. Cancer Res. 6, 735-742.

Connelly, C. M., Thomas, M., and Deiters, A. (2012). High-throughput luciferase reporter assay for smallmolecule inhibitors of microRNA function. J. Biomol. Screen.

Crew, E., Rahman, S., Razzak-Jaffar, A., Mott, D., Kamundi, M., Yu, G., Tchah, N., Lee, J., Bellavia, M., and Zhong, C. J. (2012). MicroRNA conjugated gold nanoparticles and cell transfection. Anal. Chem. 84, 26-29. de Araujo, M. F., Hori, E., Maior, R. S., Tomaz, C., Ono, T., and Nishijo, H. (2012). Neuronal activity of the anterior cingulate cortex during an observation-based decision making task in monkeys. Behav. Brain Res. 230, 48-61.

Delay, C., Calon, F., Mathews, P., Hebert, S. S. (2011). Alzheimer-specific variants in the 3'UTR of Amyloid precursor protein affect microRNA function. Mol. Neurodegener. 6, 70.

Eipper-Mains, J. E., Kiraly, D. D., Palakodeti, D., Mains, R. E., Eipper, B. A., and Graveley, B. R. (2011). MicroRNA-Seq reveals cocaineregulated expression of striatal microRNAs. RNA 17, 1529-1543.

Elmen, J., Lindow, M., Schutz, S., Lawrence, M., Petri, A., Obad, S., Lindholm, M., Hedtjarn, M., Hansen, H. F., Berger, U., Gullans, S., Kearney, P., Sarnow, P., Straarup, E. M., and Kauppinen, S. (2008). LNAmediated microRNA silencing in non-human primates. Nature 452, 896-899.

Enciu, A. M., Popescu, B. O., and Gheorghisan-Galateanu, A. (2012). MicroRNAs in brain development and degeneration. Mol. Biol. Rep. 39, 2243-2252.

Fenelon, K., Mukai, J., Xu, B., Hsu, P. K., Drew, L. J., Karayiorgou, M., Fischbach, G. D., Macdermott, A. B., and Gogos, J. A. (2011). Deficiency of Dgcr8, a gene disrupted by the $22 \mathrm{q} 11.2$ microdeletion, results in altered short-term plasticity in the prefrontal cortex. Proc. Natl. Acad. Sci. U.S.A. 108, 4447-4452.

Gao, F. B. (2010). Context-dependent functions of specific microRNAs in neuronal development. Neural Dev. 5,25 .

Gao, J., Wang, W. Y., Mao, Y. W., Graff, J., Guan, J. S., Pan, L., Mak, G., Kim, D., Su, S. C., and Tsai, L. H. (2010). A novel pathway regulates memory and plasticity via SIRT 1 and miR-134. Nature 466, 1105-1109.

Gardiner, E., Beveridge, N. J., Wu, J. Q., Carr, V., Scott, R. J., Tooney, P. A., and Cairns, M. J. (2011). Imprinted DLK1-DIO3 region of 14q32 defines a schizophreniaassociated miRNA signature in peripheral blood mononuclear cells. Mol. Psychiatry. 
Gaughwin, P. M., Ciesla, M., Lahiri, N., Tabrizi, S. J., Brundin, P., and Bjorkqvist, M. (2011). Hsa-miR-34b is a plasma-stable microRNA that is elevated in pre-manifest Huntington's disease. Hum. Mol. Genet. 20, 2225-2237.

Geekiyanage, H., and Chan, C. (2011). MicroRNA-137/181c regulates serine palmitoyltransferase and in turn amyloid beta, novel targets in sporadic Alzheimer's disease. J. Neurosci. 31, 14820-14830.

Geekiyanage, H., Jicha, G. A., Nelson, P. T., and Chan, C. (2011). Blood serum miRNA: Non-invasive biomarkers for Alzheimer's disease. Exp. Neurol. 235, 491-496.

Gehrke, S., Imai, Y., Sokol, N., Lu, B. (2010). Pathogenic LRRK2 negatively regulates microRNA-mediated translational repression. Nature 466, 637-641.

Ghahramani Seno, M. M., Hu, P., Gwadry, F. G., Pinto, D., Marshall, C. R., Casallo, G., and Scherer, S. W. (2011). Gene and miRNA expression profiles in autism spectrum disorders. Brain Res. 1380, 85-97.

Ghidoni, R., Benussi, L., Paterlini, A., Albertini, V., Binetti, G., and Emanuele, E. (2011). Cerebrospinal fluid biomarkers for Alzheimer's disease: the present and the future. Neurodegener. Dis. 8, 413-420.

Ghose, J., Sinha, M., Das, E., Jana, N. R., and Bhattacharyya, N. P. (2011). Regulation of miR$146 \mathrm{a}$ by RelA/NFkB and p53 in STHdh(Q111)/Hdh(Q111) cells, a cell model of Huntington's disease. PLoS One 6, e23837.

Gillardon, F., Mack, M., Rist, W., Schnack, C., Lenter, M., Hildebrandt, T., and Hengerer, B. (2008). MicroRNA and proteome expression profiling in early-symptomatic alpha-synuclein(A30P)-transgenic mice. Proteomics Clin. Appl. 2, 697-705.

Han, J., Denli, A. M., and Gage, F. H. (2012). The enemy within: intronic miR-26b represses its host gene, ctdsp2, to regulate neurogenesis. Genes Dev. 26, 6-10.

Haramati, S., Chapnik, E., Sztainberg, Y., Eilam, R., Zwang, R., Gershoni, N., McGlinn, E., Heiser, P. W., Wills, A. M., Wirguin, I., Rubin, L. L., Misawa, H., Tabin, C. J., Brown, R. Jr., Chen, A., and Hornstein, E. (2010). miRNA malfunction causes spinal motor neuron disease. Proc. Natl. Acad. Sci. U.S.A. 107, 13111-13116.

Haramati, S., Navon, I., Issler, O., Ezra-Nevo, G., Gil, S., Zwang, R., Hornstein, E., and Chen, A.
(2011). MicroRNA as repressors of stress-induced anxiety: the case of amygdalar miR-34. J. Neurosci. 31, 14191-14203.

Havelda, Z. (2010). In situ detection of miRNAs using LNA probes. Methods Mol. Biol. 592, 127-136.

He, Y., Yang, C., Kirkmire, C. M., and Wang, Z. J. (2010). Regulation of opioid tolerance by let7 family microRNA targeting the mu opioid receptor. J. Neurosci. 30, 10251-10258.

Hebert, S. S., and De Strooper, B. (2009). Alterations of the microRNA network cause neurodegenerative disease. Trends Neurosci. 32, 199-206.

Hebert, S. S., Horre, K., Nicolai, L., Bergmans, B., Papadopoulou, A. S., Delacourte, A., and De Strooper, B. (2009). MicroRNA regulation of Alzheimer's amyloid precursor protein expression. Neurobiol. Dis. 33, 422-428.

Hebert, S. S., Horre, K., Nicolai, L., Papadopoulou, A. S., Mandemakers, W., Silahtaroglu, A. N., Kauppinen, S., Delacourte, A., and De Strooper, B. (2008). Loss of microRNA cluster miR-29a/b-1 in sporadic Alzheimer's disease correlates with increased BACE1/betasecretase expression. Proc. Natl. Acad. Sci. U.S.A. 105, 6415-6420.

Hollander, J. A., Im, H. I., Amelio, A. L., Kocerha, J., Bali, P., Lu, Q., Willoughby, D., Wahlestedt, C., Conkright, M. D., and Kenny, P. J. (2010). Striatal microRNA controls cocaine intake through CREB signalling. Nature 466, 197-202.

Hu, H. Y., Guo, S., Xi, J., Yan, Z., Fu, N., Zhang, X., Menzel, C., Liang, H., Yang, H., Zhao, M., Zeng, R., Chen, W., Paabo, S., and Khaitovich, P. (2011). MicroRNA expression and regulation in human, chimpanzee, and macaque brains. PLoS Genet. 7, e1002327. doi:10.1371/journal.pgen. 1002327

Hunsberger, J. G., Austin, D. R., Chen, G., and Manji, H. K. (2009). MicroRNAs in mental health: from biological underpinnings to potential therapies. Neuromolecular Med. 11, 173-182.

Hwang do, W., Son, S., Jang, J., Youn, H., Lee, S., Lee, D., Lee, Y. S., Jeong, J. M., Kim, W. J., and Lee, D. S. (2011). A brain-targeted rabies virus glycoprotein-disulfide linked PEI nanocarrier for delivery of neurogenic microRNA. Biomaterials 32, 4968-4975.

Im, H. I., Hollander, J. A., Bali, P., and Kenny, P. J. (2010). MeCP2 controls BDNF expression and cocaine intake through homeostatic interactions with microRNA-212. Nat. Neurosci. 13, 1120-1127.

Insel, T. R. (2009). Translating scientific opportunity into public health impact: a strategic plan for research on mental illness. Arch. Gen. Psychiatry 66, 128-133.

Jiao, J., Herl, L. D., Farese, R. V., and Gao, F. B. (2010). MicroRNA-29b regulates the expression level of human progranulin, a secreted glycoprotein implicated in frontotemporal dementia. PLoS ONE 5, e10551. doi:10.1371/journal.pone.0010551

Jin, H., Yu, Y., Chrisler, W. B., Xiong, Y., Hu, D., and Lei, C. (2012). Delivery of microRNA-10b with polylysine nanoparticles for inhibition of breast cancer cell wound healing. Breast Cancer (Auckl.) 6, 9-19.

Jin, P., Zarnescu, D. C., Ceman, S., Nakamoto, M., Mowrey, J., Jongens, T. A., Nelson, D. L., Moses, K., and Warren, S. T. (2004). Biochemical and genetic interaction between the fragile X mental retardation protein and the microRNA pathway. Nat. Neurosci. 7, 113-117.

Johnson, R., Zuccato, C., Belyaev, N. D., Guest, D. J., Cattaneo, E., and Buckley, N. J. (2008). A microRNAbased gene dysregulation pathway in Huntington's disease. Neurobiol. Dis. 29, 438-445.

Juhila, J., Sipila, T., Icay, K., Nicorici, D., Ellonen, P., Kallio, A., Korpelainen, E., Greco, D., and Hovatta, I. (2011). MicroRNA expression profiling reveals miRNA families regulating specific biological pathways in mouse frontal cortex and hippocampus. PLoS ONE 6, e21495. doi:10.1371/journal.pone.0021495

Junn, E., Lee, K. W., Jeong, B. S., Chan, T. W., Im, J. Y., and Mouradian, M. M. (2009). Repression of alpha-synuclein expression and toxicity by microRNA-7. Proc. Natl. Acad. Sci. U.S.A. 106 13052-13057.

Kao, W. T., Wang, Y., Kleinman, J. E., Lipska, B. K., Hyde, T. M., Weinberger, D. R., and Law, A. J. (2010). Common genetic variation in Neuregulin 3 (NRG3) influences risk for schizophrenia and impacts NRG3 expression in human brain. Proc. Natl. Acad. Sci. U.S.A. 107, 15619-15624.

Kapsimali, M., Kloosterman, W. P., de Bruijn, E., Rosa, F., Plasterk, R. H., and Wilson, S. W. (2007). MicroRNAs show a wide diversity of expression profiles in the developing and mature central nervous system. Genome Biol. 8, R173.
Kim, A. H., Reimers, M., Maher, B., Williamson, V., McMichael, O., McClay, J. L., van den Oord, E. J., Riley, B. P., Kendler, K. S., and Vladimirov, V. I. (2010). MicroRNA expression profiling in the prefrontal cortex of individuals affected with schizophrenia and bipolar disorders. Schizophr. Res. 124, 183-191.

Kim, H., Lee, G., Ganat, Y., Papapetrou, E. P., Lipchina, I., Socci, N. D., Sadelain, M., and Studer, L. (2011). miR371-3 expression predicts neural differentiation propensity in human pluripotent stem cells. Cell Stem Cell 8, 695-706

Kim, J., Inoue, K., Ishii, J., Vanti, W. B., Voronov, S. V., Murchison, E., Hannon, G., and Abeliovich, A. (2007). A MicroRNA feedback circuit in midbrain dopamine neurons. Science 317, 1220-1224.

King, M. C., and Wilson, A. C. (1975). Evolution at two levels in humans and chimpanzees. Science 188, 107-116.

Kocerha, J., Faghihi, M. A., LopezToledano, M. A., Huang, J., Ramsey, A. J., Caron, M. G., Sales, N., Willoughby, D., Elmen, J., Hansen, H. F., Orum, H., Kauppinen, S., Kenny, P. J., and Wahlestedt, C. (2009). MicroRNA-219 modulates NMDA receptor-mediated neurobehavioral dysfunction. Proc. Natl. Acad. Sci. U.S.A. 106, 3507-3512.

Kocerha, J., Kouri, N., Baker, M., Finch, N., DeJesus-Hernandez, M., Gonzalez, J., Chidamparam, K., Josephs, K. A., Boeve, B. F., Graff-Radford, N. R., Crook, J., Dickson, D. W., and Rademakers, R. (2011). Altered microRNA expression in frontotemporal lobar degeneration with TDP43 pathology caused by progranulin mutations. BMC Genomics 12, 527. doi:10.1186/1471-2164-12-527

Konopka, W., Kiryk, A., Novak, M., Herwerth, M., Parkitna, J. R., Wawrzyniak, M., Kowarsch, A., Michaluk, P., Dzwonek, J., Arnsperger, T., Wilczynski, G., Merkenschlager, M., Theis, F. J., Kohr, G., Kaczmarek, L., and Schutz, G. (2010). MicroRNA loss enhances learning and memory in mice. J. Neurosci. 30, 14835-14842.

Lai, C. Y., Yu, S. L., Hsieh, M. H., Chen, C. H., Chen, H. Y., Wen, C. C., Huang, Y. H., Hsiao, P. C., Hsiao, C. K., Liu, C. M., Yang, P. C., Hwu, H. G., and Chen, W. J. (2011). MicroRNA expression aberration as potential peripheral blood biomarkers for schizophrenia. PLoS ONE 6, e21635. doi:10.1371/journal.pone. 0021635 
Lanford, R. E., Hildebrandt-Eriksen, E. S., Petri, A., Persson, R., Lindow, M., Munk, M. E., Kauppinen, S., and Orum, H. (2010). Therapeutic silencing of microRNA-122 in primates with chronic hepatitis $\mathrm{C}$ virus infection. Science 327, 198-201.

Lau, P., and de Strooper, B. (2010). Dysregulated microRNAs in neurodegenerative disorders. Semin. Cell Dev. Biol. 21, 768-773.

Lee, S. T., Chu, K., Im, W. S., Yoon, H. J., Im, J. Y., Park, J. E., Park, K. H., Jung, K. H., Lee, S. K., Kim, M., and Roh, J. K. (2011). Altered microRNA regulation in Huntington's disease models. Exp. Neurol. 227, 172-179.

Li, Y., Lin, L., and Jin, P. (2008). The microRNA pathway and fragile $\mathrm{X}$ mental retardation protein. Biochim. Biophys. Acta 1779, 702-705.

Li, Y. Y., Cui, J. G., Hill, J. M., Bhattacharjee, S., Zhao, Y., and Lukiw, W. J. (2011). Increased expression of miRNA-146a in Alzheimer's disease transgenic mouse models. Neurosci. Lett. 487, 94-98.

Liu, N., Landreh, M., Cao, K., Abe, M., Hendriks, G. J., Kennerdell, J. R., Zhu, Y., Wang, L. S., and Bonini, N. M. (2012a). The microRNA miR-34 modulates ageing and neurodegeneration in Drosophila. Nature 482, 519-523.

Liu, W., Liu, C., Zhu, J., Shu, P., Yin, B., Gong, Y., Qiang, B., Yuan, J., and Peng, X. (2012b). MicroRNA16 targets amyloid precursor protein to potentially modulate Alzheimer'sassociated pathogenesis in SAMP8 mice. Neurobiol. Aging 33, 522-534.

Long, J. M., and Lahiri, D. K. (2011). MicroRNA-101 downregulates Alzheimer's amyloid-beta precursor protein levels in human cell cultures and is differentially expressed. Biochem. Biophys. Res. Commun. 404, 889-895.

Lukiw, W. J. (2007). Micro-RNA speciation in fetal, adult and Alzheimer's disease hippocampus. Neuroreport $18,297-300$

Magill, S. T., Cambronne, X. A., Luikart, B. W., Lioy, D. T., Leighton, B. H., Westbrook, G. L., Mandel, G., and Goodman, R. H. (2010). microRNA132 regulates dendritic growth and arborization of newborn neurons in the adult hippocampus. Proc. Natl. Acad. Sci. U.S.A. 107, 20382-20387.

Mallick, B., and Ghosh, Z. (2011). A complex crosstalk between polymorphic microRNA target sites and AD prognosis. RNA Biol. 8, 665-673.

Margis, R., and Rieder, C. R. (2011). Identification of blood microRNAs associated to Parkinsonis disease. J. Biotechnol. 152, 96-101.
Marti, E., Pantano, L., Banez-Coronel, M., Llorens, F., Minones-Moyano, E., Porta, S., Sumoy, L., Ferrer, I., and Estivill, X. (2010). A myriad of miRNA variants in control and Huntington's disease brain regions detected by massively parallel sequencing. Nucleic Acids Res. 38, 7219-7235.

Martins, M., Rosa, A., Guedes, L. C., Fonseca, B. V., Gotovac, K., Violante, S., Mestre, T., Coelho, M., Rosa, M. M., Martin, E. R., Vance, J. M., Outeiro, T. F., Wang, L., Borovecki, F., Ferreira, J. J., and Oliveira, S. A. (2011). Convergence of miRNA expression profiling, alpha-synuclein interaction and GWAS in Parkinson's disease. PLoS ONE 6, e25443. doi:10.1371/journal.pone. 0025443

McConkey, E. H., and Varki, A. (2000). A primate genome project deserves high priority. Science 289, 1295-1296.

Mellios, N., Sugihara, H., Castro, J., Banerjee, A., Le, C., Kumar, A., Crawford, B., Strathmann, J., Tropea, D., Levine, S. S., Edbauer, D., and Sur, M. (2011). miR-132, an experiencedependent microRNA, is essential for visual cortex plasticity. Nat. Neurosci. 14, 1240-1242.

Minones-Moyano, E., Porta, S., Escaramis, G., Rabionet, R., Iraola, S., Kagerbauer, B., Espinosa-Parrilla, Y., Ferrer, I., Estivill, X., and Marti, E. (2011). MicroRNA profiling of Parkinson's disease brains identifies early downregulation of $\mathrm{miR}-34 \mathrm{~b} / \mathrm{c}$ which modulate mitochondrial function. Hum. Mol. Genet. 20, 3067-3078.

Montgomery, R. L., and van Rooij, E. (2011). Therapeutic advances in MicroRNA targeting. J. Cardiovasc. Pharmacol. 57, 1-7.

Moreau, M. P., Bruse, S. E., David-Rus, R., Buyske, S., and Brzustowicz, L. M. (2011). Altered microRNA expression profiles in postmortem brain samples from individuals with schizophrenia and bipolar disorder. Biol. Psychiatry 69, 188-193.

Mouillet-Richard, S., Baudry, A., Launay, J. M., and Kellermann, O. (2011). MicroRNAs and depression. Neurobiol. Dis. 46, 272-278.

Mouradian, M. M. (2012). MicroRNAs in Parkinson's disease. Neurobiol. Dis. 46, 279-284.

Nelson, P. T., and Wang, W. X. (2010). MiR-107 is reduced in Alzheimer's disease brain neocortex: validation study. J. Alzheimers Dis. 21, 75-79.

Nunez-Iglesias, J., Liu, C. C., Morgan, T. E., Finch, C. E., and Zhou, X. J. (2010). Joint genome-wide profiling of miRNA and mRNA expression in Alzheimer's disease cortex reveals altered miRNA regulation. PLoS ONE 5, e8898. doi:10.1371/journal.pone. 0008898

Obad, S., dos Santos, C. O., Petri, A., Heidenblad, M., Broom, O., Ruse, C., Fu, C., Lindow, M., Stenvang, J., Straarup, E. M., Hansen, H. F., Koch, T., Pappin, D., Hannon, G. J. and Kauppinen, S. (2011). Silencing of microRNA families by seedtargeting tiny LNAs. Nat. Genet. 43 , 371-378.

O'Connor, R. M., Dinan, T. G., and Cryan, J. F. (2011). Little things on which happiness depends: microRNAs as novel therapeutic targets for the treatment of anxiety and depression. Mol. Psychiatry 17, 359-376.

Paabo, S. (2001). Genomics and society. The human genome and our view of ourselves. Science 291, 1219-1220.

Packer, A. N., Xing, Y., Harper, S. Q., Jones, L., and Davidson, B. L. (2008). The bifunctional microRNA miR-9/miR-9* regulates REST and CoREST and is downregulated in Huntington's disease. J. Neurosci. 28 , 14341-14346.

Park, J. E., Heo, I., Tian, Y., Simanshu, D. K., Chang, H., Jee, D., Patel, D. J. and Kim, V. N. (2011). Dicer recognizes the 5' end of RNA for efficient and accurate processing. Nature 475 , 201-205.

Patel, N., Hoang, D., Miller, N., Ansaloni, S., Huang, Q., Rogers, J. T., Lee, J. C., and Saunders, A. J. (2008). MicroRNAs can regulate human APP levels. Mol. Neurodegener. 3, 10.

Perkins, D. O., Jeffries, C. D., Jarskog, L. F., Thomson, J. M., Woods, K., Newman, M. A., Parker, J. S., Jin, J., and Hammond, S. M. (2007). microRNA expression in the prefrontal cortex of individuals with schizophrenia and schizoaffective disorder. Genome Biol. 8, R27.

Perkins, T., Stokes, M., McGillivray, J., and Bittar, R. (2010). Mirror neuron dysfunction in autism spectrum disorders. J. Clin. Neurosci. 17, 1239-1243.

Persengiev, S. P., Kondova, II, and Bontrop, R. E. (2012). The impact of microRNAs on brain aging and neurodegeneration. Curr. Gerontol. Geriatr. Res. 2012, 359369.

Petri, A., Lindow, M., and Kauppinen, S. (2009). MicroRNA silencing in primates: towards development of novel therapeutics. Cancer Res. 69, 393-395.

Pietrzykowski, A. Z., Friesen, R. M., Martin, G. E., Puig, S. I., Nowak, C. L., Wynne, P. M., Siegelmann, H. T., and Treistman, S. N. (2008).
Posttranscriptional regulation of BK channel splice variant stability by miR-9 underlies neuroadaptation to alcohol. Neuron 59, 274-287.

Rademakers, R., Eriksen, J. L., Baker, M., Robinson, T., Ahmed, Z., Lincoln, S. J., Finch, N., Rutherford, N. J., Crook, R. J., Josephs, K. A., Boeve, B. F., Knopman, D. S., Petersen, R. C., Parisi, J. E., Caselli, R. J., Wszolek, Z. K., Uitti, R. J., Feldman, H., Hutton, M. L., Mackenzie, I. R., GraffRadford, N. R., and Dickson, D. W. (2008). Common variation in the miR-659 binding-site of GRN is a major risk factor for TDP43positive frontotemporal dementia. Hum. Mol. Genet. 17, 3631-3642.

Rajasethupathy, P., Fiumara, F., Sheridan, R., Betel, D., Puthanveettil, S. V., Russo, J. J., Sander, C., Tuschl, T., and Kandel, E. (2009). Characterization of small RNAs in Aplysia reveals a role for miR-124 in constraining synaptic plasticity through CREB. Neuron 63, 803-817.

Remenyi, J., Hunter, C. J., Cole, C., Ando, H., Impey, S., Monk, C. E., Martin, K. J., Barton, G. J., Hutvagner, G., and Arthur, J. S. (2010). Regulation of the miR-212/132 locus by MSK1 and CREB in response to neurotrophins. Biochem. J. 428, 281-291.

Richardson, K., Lai, C. Q., Parnell, L. D., Lee, Y. C., and Ordovas, J. M. (2011). A genome-wide survey for SNPs altering microRNA seed sites identifies functional candidates in GWAS. BMC Genomics 12, 504 doi:10.1186/1471-2164-12-504

Ripke, S., Sanders, A. R., Kendler, K. S., Levinson, D. F., Sklar, P., Holmans, P. A., Lin, D. Y., Duan, J., Ophoff, R. A., Andreassen, O. A., Scolnick, E., Cichon, S., St Clair, D., Corvin, A., Gurling, H., Werge, T., Rujescu, D., Blackwood, D. H., Pato, C. N., Malhotra, A. K., Purcell, S., Dudbridge, F., Neale, B. M., Rossin, L., Visscher, P. M., Posthuma, D., Ruderfer, D. M., Fanous, A., Stefansson, H. Steinberg, S., Mowry, B. J., Golimbet, V., De Hert, M., Jonsson, E. G., Bitter, I., Pietilainen, O. P., Collier, D. A., Tosato, S., Agartz, I., Albus, M., Alexander, M., Amdur, R. L., Amin, F., Bass, N., Bergen, S. E., Black, D. W., Borglum, A. D., Brown, M. A., Bruggeman, R., Buccola, N. G., Byerley, W. F., Cahn, W., Cantor, R. M., Carr, V. J., Catts, S. V., Choudhury, K., Cloninger, C. R., Cormican, P., Craddock, N., Danoy, P. A., Datta, S., de Haan, L., Demontis, D., Dikeos, D., Djurovic, S., Donnelly, P., Donohoe, G., Duong, L., Dwyer, S., Fink-Jensen, A., Freedman, R., Freimer, N. B., Friedl, M., Georgieva, 
L., Giegling, I., Gill, M., Glenthoj, B., Godard, S., Hamshere, M., Hansen, M., Hansen, T., Hartmann, A. M., Henskens, F. A., Hougaard, D. M., Hultman, C. M., Ingason, A., Jablensky, A. V., Jakobsen, K. D., Jay, M., Jurgens, G., Kahn, R. S., Keller, M. C., Kenis, G., Kenny, E., Kim, Y., Kirov, G. K., Konnerth, H., Konte, B., Krabbendam, L., Krasucki, R., Lasseter, V. K., Laurent, C., Lawrence, J., Lencz, T., Lerer, F. B., Liang, K. Y., Lichtenstein, P., Lieberman, J. A., Linszen, D. H., Lonnqvist, J., Loughland, C. M., Maclean, A. W., Maher, B. S., Maier, W., Mallet, J., Malloy, P., Mattheisen, M., Mattingsdal, M., McGhee, K. A., McGrath, J. J., McIntosh, A., McLean, D. E., McQuillin, A., Melle, I., Michie, P. T., Milanova, V., Morris, D. W., Mors, O., Mortensen, P. B., Moskvina, V., Muglia, P., Myin-Germeys, I., Nertney, D. A., Nestadt, G., Nielsen, J., Nikolov, I., Nordentoft, M., Norton, N., Nothen, M. M., O'Dushlaine, C. T., Olincy, A., Olsen, L., O'Neill, F. A., Orntoft, T. F., Owen, M. J., Pantelis, C., Papadimitriou, G., Pato, M. T., Peltonen, L., Petursson, H., Pickard, B., Pimm, J., Pulver, A. E., Puri, V., Quested, D., Quinn, E. M., Rasmussen, H. B., Rethelyi, J. M., Ribble, R., Rietschel, M., Riley, B. P., Ruggeri, M., Schall, U., Schulze, T. G., Schwab, S. G., Scott, R. J., Shi, J., Sigurdsson, E., Silverman, J. M., Spencer, C. C., Stefansson, K., Strange, A., Strengman, E., Stroup, T. S., Suvisaari, J., Terenius, L., Thirumalai, S., Thygesen, J. H., Timm, S., Toncheva, D., van den Oord, E., van Os, J., van Winkel, R., Veldink, J., Walsh, D., Wang, A. G., Wiersma, D., Wildenauer, D. B., Williams, H. J., Williams, N. M., Wormley, B., Zammit, S., Sullivan, P. F., O’Donovan, M. C., Daly, M. J., and Gejman, P. V. (2011). Genome-wide association study identifies five new schizophrenia loci. Nat. Genet. 43, 969-976.

Ruberti, F., Barbato, C., and Cogoni, C. (2011). Targeting microRNAs in neurons: tools and perspectives. Exp. Neurol. 235, 419-426.

Saba, R., Storchel, P. H., Aksoy-Aksel, A., Kepura, F., Lippi, G., Plant, T. D., and Schratt, G. M. (2012). Dopamineregulated microRNA MiR-181a controls GluA2 surface expression in hippocampal neurons. Mol. Cell. Biol. 32, 619-632.

Santarelli, D. M., Beveridge, N. J., Tooney, P. A., and Cairns, M. J. (2011). Upregulation of dicer and microRNA expression in the dorsolateral prefrontal cortex Brodmann area 46 in schizophrenia. Biol. Psychiatry 69, 180-187.

Sarachana, T., Zhou, R., Chen, G., Manji, H. K., and Hu, V. W. (2010). Investigation of post-transcriptional gene regulatory networks associated with autism spectrum disorders by microRNA expression profiling of lymphoblastoid cell lines. Genome Med. 2, 23.

Saus, E., Soria, V., Escaramis, G., Vivarelli, F., Crespo, J. M., Kagerbauer, B., Menchon, J. M., Urretavizcaya, M., Gratacos, M., and Estivill, X. (2010). Genetic variants and abnormal processing of pre-miR182, a circadian clock modulator, in major depression patients with late insomnia. Hum. Mol. Genet. 19, 4017-4025.

Schipper, H. M., Maes, O. C., Chertkow, H. M., and Wang, E. (2007). MicroRNA expression in Alzheimer blood mononuclear cells. Gene Regul. Syst. Bio. 1, 263-274.

Schofield, C. M., Hsu, R., Barker, A. J., Gertz, C. C., Blelloch, R., and Ullian, E. M. (2011). Monoallelic deletion of the microRNA biogenesis gene Dgcr8 produces deficits in the development of excitatory synaptic transmission in the prefrontal cortex. Neural Dev. 6, 11.

Schonrock, N., Ke, Y. D., Humphreys, D., Staufenbiel, M., Ittner, L. M., Preiss, T., and Gotz, J. (2010). Neuronal microRNA deregulation in response to Alzheimer's disease amyloid-beta. PLoS ONE 5, el1070. doi:10.1371/journal.pone.0011070

Seto, A. G. (2010). The road toward microRNA therapeutics. Int. J. Biochem. Cell Biol. 42, 1298-1305.

Shaltiel, G., Hanan, M., Wolf, Y., Barbash, S., Kovalev, E., Shoham, S., and Soreq, H. (2012). Hippocampal microRNA-132 mediates stressinducible cognitive deficits through its acetylcholinesterase target. Brain Struct. Funct.

Shi, S. J., Zhong, Z. R., Liu, J., Zhang, Z. R., Sun, X., and Gong, T. (2012). Solid lipid nanoparticles loaded with anti-microRNA oligonucleotides (AMOs) for suppression of microRNA-21 functions in human lung cancer cells. Pharm. Res. 29, 97-109.

Shi, Y., Zhao, X., Hsieh, J., Wichterle, H., Impey, S., Banerjee, S., Neveu, P., and Kosik, K. S. (2010). MicroRNA regulation of neural stem cells and neurogenesis. J. Neurosci. 30, 14931-14936.

Shibata, M., Kurokawa, D., Nakao, H., Ohmura, T., and Aizawa, S. (2008). MicroRNA-9 modulates
Cajal-Retzius cell differentiation by suppressing Foxgl expression in mouse medial pallium. J. Neurosci. 28, 10415-10421.

Shibata, M., Nakao, H., Kiyonari, H., Abe, T., and Aizawa, S. (2011). MicroRNA-9 regulates neurogenesis in mouse telencephalon by targeting multiple transcription factors. J. Neurosci. 31, 3407-3422.

Shioya, M., Obayashi, S., Tabunoki, H., Arima, K., Saito, Y., Ishida, T., and Satoh, J. (2010). Aberrant microRNA expression in the brains of neurodegenerative diseases: miR29a decreased in Alzheimer disease brains targets neurone navigator 3 . Neuropathol. Appl. Neurobiol. 36, 320-330.

Sinha, M., Ghose, J., Das, E. and Bhattarcharyya, N. P. (2010). Altered microRNAs in STHdh(Q111)/Hdh(Q111) cells: miR-146a targets TBP. Biochem. Biophys. Res. Commun. 396, 742-747.

Smalheiser, N. R., Lugli, G., Rizavi, H. S., Torvik, V. I., Turecki, G., and Dwivedi, Y. (2012). MicroRNA expression is down-regulated and reorganized in prefrontal cortex of depressed suicide subjects. PLoS One 7, e33201.

Smith, P. Y., Delay, C., Girard, J., Papon, M. A., Planel, E., Sergeant, N., Buee, L., and Hebert, S. S. (2011). MicroRNA-132 loss is associated with tau exon 10 inclusion in progressive supranuclear palsy. Hum. Mol. Genet. 20, 4016-4024.

Stenvang, J., Silahtaroglu, A. N. Lindow, M., Elmen, J., and Kauppinen, S. (2008). The utility of LNA in microRNA-based cancer diagnostics and therapeutics. Semin. Cancer Biol. 18, 89-102.

Sun, G., Yan, J., Noltner, K., Feng, J., Li, H., Sarkis, D. A., Sommer, S. S., and Rossi, J. J. (2009). SNPs in human miRNA genes affect biogenesis and function. RNA 15, 1640-1651

Tal, T. L., Franzosa, J. A., Tilton, S C., Philbrick, K. A., Iwaniec, U. T., Turner, R. T., Waters, K. M., and Tanguay, R. L. (2012). MicroRNAs control neurobehavioral development and function in zebrafish. FASEB J.

Tao, J., Wu, H., Lin, Q., Wei, W., Lu, X. H., Cantle, J. P., Ao, Y., Olsen, R. W. Yang, X. W., Mody, I., Sofroniew, M. V., and Sun, Y. E. (2011). Deletion of astroglial Dicer causes non-cellautonomous neuronal dysfunction and degeneration. J. Neurosci. 31, 8306-8319.
Thompson, W. K., Hallmayer, J., and O'Hara, R. (2011). Design considerations for characterizing psychiatric trajectories across the lifespan: application to effects of APOEepsilon 4 on cerebral cortical thickness in Alzheimer's disease. Am. J. Psychiatry 168, 894-903.

Vo, N., Klein, M. E., Varlamova, O., Keller, D. M., Yamamoto, T., Goodman, R. H., and Impey, S. (2005). A cAMP-response element binding protein-induced microRNA regulates neuronal morphogenesis. Proc. Natl. Acad. Sci. U.S.A. 102, 16426-16431.

Waber, D. P., Forbes, P. W., Almli, C. R., and Blood, E. A. (2012). Fouryear longitudinal performance of a population-based sample of healthy children on a neuropsychological battery: The NIH MRI Study of normal brain development. J. Int. Neuropsychol. Soc. 18, 179-190.

Wang, H., Liu, J., Zong, Y., Xu, Y., Deng, W., Zhu, H., Liu, Y., Ma, C., Huang, L., Zhang, L., and Qin, C. (2010). miR-106b aberrantly expressed in a double transgenic mouse model for Alzheimer's disease targets TGF-beta type II receptor. Brain Res. 1357, 166-174.

Wang, W. X., Huang, Q., Hu, Y., Stromberg, A. J., and Nelson, P. T. (2011). Patterns of microRNA expression in normal and early Alzheimer's disease human temporal cortex: white matter versus gray matter. Acta Neuropathol. 121, 193-205.

Wang, W. X., Rajeev, B. W., Stromberg, A. J., Ren, N., Tang, G., Huang, Q., Rigoutsos, I., Nelson, P. T. (2008). The expression of microRNA miR107 decreases early in Alzheimer's disease and may accelerate disease progression through regulation of beta-site amyloid precursor proteincleaving enzyme 1. J. Neurosci. 28, 1213-1223.

Wang, W. X., Wilfred, B. R., Madathil, S. K., Tang, G., Hu, Y., Dimayuga, J., Stromberg, A. J., Huang, Q., Saatman, K. E., and Nelson, P. T. (0000). miR-107 regulates granulin/progranulin with implications for traumatic brain injury and neurodegenerative disease. Am. J. Pathol. 177, 334-345.

Wang, X., Liu, P., Zhu, H., Xu, Y., Ma, C., Dai, X., Huang, L., Liu, Y., Zhang, L., and Qin, C. (2009). miR$34 \mathrm{a}$, a microRNA up-regulated in a double transgenic mouse model of Alzheimer's disease, inhibits bcl2 translation. Brain Res. Bull. 80, 268-273.

Williams, A. H., Valdez, G., Moresi, V., Qi, X., McAnally, J., Elliott, J. L., 
Bassel-Duby, R., Sanes, J. R., and Olson, E. N. (2009). MicroRNA206 delays ALS progression and promotes regeneration of neuromuscular synapses in mice. Science 326, 1549-1554.

Xu, Y., Li, F., Zhang, B., Zhang, K., Zhang, F., Huang, X., Sun, N., Ren, Y., Sui, M., and Liu, P. (2010a). MicroRNAs and target site screening reveals a pre-microRNA-30e variant associated with schizophrenia. Schizophr. Res. 119, 219-227.

Xu, Y., Liu, H., Li, F., Sun, N., Ren, Y., Liu, Z., Cao, X., Wang, Y., Liu, P., and Zhang, K. (2010b). A polymorphism in the microRNA-30e precursor associated with major depressive disorder risk and P300 waveform. J. Affect. Disord. 127, 332-336.

Yang, R., Dai, Z., Chen, S., and Chen, L. (2011). MicroRNA-mediated gene regulation plays a minor role in the transcriptomic plasticity of cold-acclimated zebrafish brain tissue. BMC Genomics 12, 605. doi:10.1186/1471-2164-12-605
Yang, S. H., Cheng, P. H., Banta, H., Piotrowska-Nitsche, K., Yang, J. J., Cheng, E. C., Snyder, B., Larkin, K., Liu, J., Orkin, J., Fang, Z. H., Smith, Y., Bachevalier, J., Zola, S. M., Li, S. H., Li, X. J., and Chan, A. W. (2008). Towards a transgenic model of Huntington's disease in a non-human primate. Nature 453, 921-924.

Yang, Y., Xu, S., Xia, L., Wang, J., Wen, S., Jin, P., and Chen, D. (2009). The bantam microRNA is associated with drosophila fragile $\mathrm{X}$ mental retardation protein and regulates the fate of germline stem cells. PLoS Genet. 5, e1000444. doi:10.1371/journal.pgen.1000444

Yao, J., Hennessey, T., Flynt, A., Lai, E., Beal, M. F., Lin, M. T. (2010). MicroRNA-related cofilin abnormality in Alzheimer's disease. PLoS One 5:e15546.

Zhang, X. Y., Yang, Z. Y., Li, J. M., Li, H. X., Wang, L., Gong, Q. Y., and Zhou, D. (2012). Longitudinal (1) $\mathrm{H}$ MRS assessment of the thalamus in a Coriaria lactone-induced rhesus monkey status epilepticus model. NMR Biomed.

Zhou, R., Yuan, P., Wang, Y., Hunsberger, J. G., Elkahloun, A., Wei, Y., Damschroder-Williams, P., Du, J., Chen, G., and Manji, H. K. (2009). Evidence for selective microRNAs and their effectors as common long-term targets for the actions of mood stabilizers. Neuropsychopharmacology 34 1395-1405.

Zhu, Y., Kalbfleisch, T., Brennan, M. D., and Li, Y. (2009). A MicroRNA gene is hosted in an intron of a schizophrenia-susceptibility gene. Schizophr. Res. 109, 86-89.

Zovoilis, A., Agbemenyah, H. Y., AgisBalboa, R. C., Stilling, R. M., Edbauer, D., Rao, P., Farinelli, L., Delalle, I., Schmitt, A., Falkai, P., Bahari-Javan, S., Burkhardt, S., Sananbenesi, F., Fischer, A. (2011). MicroRNA-34c is a novel target to treat dementias. EMBO J 30 4299-4308.
Conflict of Interest Statement: The authors declare that the research was conducted in the absence of any commercial or financial relationships that could be construed as a potential conflict of interest.

Received: 20 March 2012; paper pending published: 10 April 2012; accepted: 26 April 2012; published online: 17 May 2012.

Citation: Chan AWS and Kocerha J (2012) The path to microRNA therapeutics in psychiatric and neurodegenerative disorders. Front. Gene. 3:82. doi: 10.3389/fgene.2012.00082

This article was submitted to Frontiers in Non-Coding RNA, a specialty of Frontiers in Genetics.

Copyright (C) 2012 Chan and Kocerha. This is an open-access article distributed under the terms of the Creative Commons Attribution Non Commercial License, which permits non-commercial use, distribution, and reproduction in other forums, provided the original authors and source are credited. 